\title{
Ras oncogene and Hypoxia-inducible factor-1 alpha (hif-1 $\alpha$ ) expression in the Amazon fish Colossoma macropomum (Cuvier, 1818) exposed to benzo[a]pyrene.
}

Grazyelle Sebrenski da Silva ${ }^{1,2}$,Luciana Mara Lopes Fé ${ }^{1}$, Maria de Nazaré Paula da Silva ${ }^{1}$ and Vera Maria Fonseca de Almeida e $\mathrm{Val}^{1}$

${ }^{1}$ Laboratory of Ecophysiology and Molecular Evolution (LEEM), Instituto Nacional de Pesquisas da Amazônia (INPA), Manaus, AM, Brazil.

${ }^{2}$ Department of Morphology of the Institute of Biological Sciences (DM-ICB) Universidade Federal do Amazonas (UFAM), Manaus, AM, Brazil.

\begin{abstract}
Benzo[a]pyrene $(\mathrm{B}[\mathrm{a}] \mathrm{P})$ is a petroleum derivative capable of inducing cancer in human and animals. In this work, under laboratory conditions, we analyzed the responses of Colossoma macropomum to B[a]P acute exposure through intraperitoneal injection of four different B[a]P concentrations $(4,8,16$ and $32 \mu \mathrm{mol} / \mathrm{kg})$ or corn oil (control group). We analyzed expression of the ras oncogene and the Hypoxia-inducible factor-1 alpha (hif-1 $\alpha$ ) gene using quantitative real-time PCR. Additionally, liver histopathological changes and genotoxic effects were evaluated through the comet assay. Ras oncogene was overexpressed in fish exposed to 4,8 of $16 \mu \mathrm{mol} / \mathrm{kg} \mathrm{B}[\mathrm{a}] \mathrm{P}$, showing $4.96,7.10$ and 6.78 -fold increases, respectively. Overexpression also occurred in hif- $1 \alpha$ in fish injected with 4 and $8 \mu \mathrm{mol} / \mathrm{kg} \mathrm{B}[\mathrm{a}] \mathrm{P}$, showing 8.82 and 4.64-fold increases, respectively. Histopathological damage in fish liver was classified as irreparable in fish exposed to 8,16 and $32 \mu \mathrm{mol} / \mathrm{kg} \mu \mathrm{M}$ B[a]P. The genotoxic damage increased in fish injected with 8 and 16 $\mu \mathrm{mol} / \mathrm{kg}$ in comparison with the control group. Acute exposure of B[a]P was capable to interrupt the expression of ras oncogene and hif-1 $\alpha$, and increase DNA breaks due to tissue damage.
\end{abstract}

Keywords: Ras oncogene, hif-1 $\alpha$, tambaqui, $\mathrm{B}[\mathrm{a}] \mathrm{P}$, genotoxic damage.

Received: March 15, 2016; Accepted: October 05, 2016.

\section{Introduction}

Polycyclic aromatic hydrocarbons (PAHs) belong to a class of petroleum derivatives with high carcinogenic, mutagenic and genotoxic potential (Buhler and Williams, 1989, Vienneau et al., 1995, Tsukatani et al., 2003). PAHs are considered relevant threats to aquatic environments and are common contaminants in industrialized areas, mainly affecting inland and coastal water bodies, where organically enriched sediments or suspended particles may occur (Harris et al., 1985, Meador et al., 1995). PAHs contaminants can arise from natural sources, such as oil seeps, volcanoes, and forest fires, or from anthropogenic sources, as burning fuel, power generation, and oil spill (Latimer and Zheng, 2003).

Benzo[a]pyrene (B[a]P) is the most dangerous $\mathrm{PAH}$, classified as Group 1 substance (IARC, International Agen-

Send correspondence to Grazyelle Sebrenski da Silva. Laboratory of Ecophysiology and Molecular Evolution (LEEM), Instituto Nacional de Pesquisas da Amazônia (INPA), Avenida André Araújo 2936, 69067-375. Manaus, AM, Brazil. E-mail: grazysebrenski@ hotmail.com cy for Research on Cancer, 2012). B[a]P is an immunosuppressive and pro-inflammatory agent, known as one of the most potent carcinogen (Pryor and Stone, 1993, Jaakkola and Jaakkola, 1997). To accomplish its carcinogenic action, $\mathrm{B}[\mathrm{a}] \mathrm{P}$ breaks down into reactive intermediates that covalently bind to DNA and cause a guanine (G)-thymine (T) transversion (Conney et al., 1994).

The effects of $\mathrm{B}[\mathrm{a}] \mathrm{P}$ contamination have been studied in different groups of organisms such as fish (Padrós et al., 2003), mussels (Tintos et al., 2008), snails (Sanches-Arguello et al., 2012), and mice (Gao et al., 2011). Fish absorb PAHs from water via their body surface or gills and also by ingesting contaminated food or sediment (Varanasi et al., 1989). In fish, exposure to PAHs results in the induction of enzymatic systems involved in the metabolism of xenobiotic compounds to detoxify the organism (Buhler and Williams, 1989). Additionally, histological alterations also occur in the liver of fish exposed to B[a]P. Oliveira-Ribeiro et al. (2007) described degenerative lesions, nuclear pleomorphism, pre-neoplastic proliferative conditions and necrosis as typical lesions in the fish liver. Due to strikingly similar histopathological features between fish and human 
tumors, fish have been used as models in cancer research (Lam et al., 2006).

Recently, gene expression profiling has attracted researchers as a means of comparing the molecular features of tumors among different vertebrate species (Grabher and Thomas, 2006). For instance, rainbow trout (Oncorhynchus mykiss) has many advantages as a human carcinogenesis study model. These characteristics include the effects of PAHs (Bailey et al., 1987, 1996) and the responses of some genes, such as ras oncogenes (Rotchell et al., 2001).

Ras proteins that play a central role in cell growth signaling cascades. To date, several ras genes are characterized in fish, and have a high degree of similarity with mammalian nucleotide and deduced amino acid sequences. In fact, some species of fish have been used as models to understand ras genes behavior and their homology with human genes (Rotchell et al., 2001). Goldfish (Carassius auratus) was the first fish to have its ras gene studied by Nemoto et al. (1986). Later, other fish species were investigated such as rainbow trout (Mangold et al., 1991), zebrafish (Danio rerio) (Cheng et al., 1997) and medaka (Oryzias latipes) (Rotchell et al., 2001).

Another gene related to cancer development is Hypoxia-inducible factor-1 alpha (hif-l $\alpha$ ), which produces the protein (HIF-1 $\alpha$ ) that is the major regulator of oxygendependent gene expression (Maxwell et al., 1997, Maxwell, 2005, Rytkönen et al., 2008, Fraga et al., 2009). The levels of hif- $1 \alpha$ expression are associated with tumorigenesis and angiogenesis (Zhong et al., 1999). Although hif- $1 \alpha$ has been mostly associated with hypoxic responses in fish, tumor cell hypoxia is also a well-studied system (Geng et al., 2014). Tumor investigation is now seen as an integral part of the basic biological approach to elucidate the common mechanisms of cancer at different phylogenetic levels (Van Beneden et al., 1990).

In Brazil, tambaqui (Colossoma macropomum) is one of the largest freshwater fish species. This species belongs to the Characidae family and is endemic to the Amazon basin. It is found mainly in rivers and in floodplain lakes (Várzea Lakes) (Marcuschi et al., 2010). In the Amazon basin, tambaqui is one of the most important commercial fish (Val and Honczaryk, 1995). It also presents many characteristics of an appropriate bioindicator species for biomonitoring programs (Salazar-Lugo et al., 2011).

Herein, we report the acute effects of $\mathrm{B}[\mathrm{a}] \mathrm{P}$ injections in tambaqui on ras oncogene expression as well as on hif-l $\alpha$ gene expression. We used fish liver to investigate gene expression and histopathological damages, and peripheral blood to investigate the genotoxic effects of $\mathrm{B}[\mathrm{a}] \mathrm{P}$.

\section{Materials and Methods}

\section{Animals}

Juveniles of C. macropomum (24.76 $\pm 5.45 \mathrm{~g} ; 10.50 \pm$ $0.64 \mathrm{~cm}$ ) were purchased from a local fish farm nearby Manaus city (Santo Antônio Farm), Amazon State (Brazil). Fish were transported to the Laboratory of Ecophysiology and Molecular Evolution at the National Institute for Amazonian Research (LEEM - INPA). Fish were held indoors in fish tanks supplied with recirculating aerated INPA's groundwater (in $\mu \mathrm{mol} \mathrm{L}{ }^{-1}\left[\mathrm{Na}^{+}\right], 43 ;\left[\mathrm{K}^{+}\right], 10 ;\left[\mathrm{Ca}^{2+}\right], 9$; $\left[\mathrm{Mg}^{2+}\right], 4 ;\left[\mathrm{Cl}^{-}\right], 31 ;\left[\mathrm{Cu}^{2+}\right], 7.0 \mu \mathrm{gL}^{-1}$; hardness $=1.33$ $\mathrm{CaCO}_{3} \mathrm{mgL}^{-1} ; \mathrm{pH}=6.80$ ); and fed once a day with commercial feed containing $36 \%$ protein. Fish were monitored daily during the acclimation period (7 days).

After the first acclimation period, 15 animals were transferred to six plastic tanks ( 70 L capacity) containing water with constant aeration. Each fish was weighed and measured, to calculate the amount of pollutant to be intraperitoneally injected. Then, fish were allowed to acclimate in these tanks for at least seven days before beginning the tests. Physicochemical parameters were measured over the course of the experiment using a digital oxygen meter YSI (Yellow Springs Instruments, USA) model 55/12-155 for temperature $\left(26.05 \pm 0.23{ }^{\circ} \mathrm{C}\right)$ and dissolved oxygen $(7.45 \pm 0.21$ $\mathrm{mg} / \mathrm{L}$ ). A digital pH-meter UltraBASIC UB-10 (Denver 156 Instrument) was used to measure the $\mathrm{pH}(5.75 \pm 0.16)$.

After one week of acclimation, feeding was suspended and fish starved for $24 \mathrm{~h}$ before starting the acute experiment (96 h). Each fish received an injection volume in accordance with the weight. Independently of treatment, the volume of the vehicle to be injected (corn oil) was calculated using a weight ratio $(0.01 \mathrm{~mL} / \mathrm{g})$. We followed the recommended protocols described in the Brazilian Guides of Animal Care and Use, and as required by the Ethics Committee on Animal Use of the National Institute for Amazonian Research (CEUA - INPA) (Protocol Number 011/2013). Sample size was the minimum required for each method, observing the literature and CONCEA recommendations. We used five treatments for the whole experiment ( $n=10$ for each treatment): i) control group, injected with corn oil; and the other four groups injected with a solution containing corn oil as vehicle and four concentrations of $\mathrm{B}$ [a]P as follows: ii) $4 \mu \mathrm{mol} / \mathrm{kg} \mathrm{B}[\mathrm{a}] \mathrm{P}$, iii) $8 \mu \mathrm{mol} / \mathrm{kg} \mathrm{B}[\mathrm{a}] \mathrm{P}$, iv) $16 \mu \mathrm{mol} / \mathrm{kg} \mathrm{B}[\mathrm{a}] \mathrm{P}$, and v) $32 \mu \mathrm{mol} / \mathrm{kg} \mathrm{B}[\mathrm{a}] \mathrm{P}$. Before receiving the injection, animals were anesthetized on ice, and after the injection they were kept in the tanks for $96 \mathrm{~h}$. After this period, blood was sampled with a heparinized syringe from the caudal vein, and then fish were euthanized through cerebral concussion followed by severing of the anterior spinal cord. The fish liver was dissected and one portion was snap-frozen in liquid nitrogen and stored at $-80^{\circ} \mathrm{C}$. The other portion was fixed in Alfac solution as described below for histopathology analysis through light microscopy. 


\section{Histopathology analysis of liver}

Six liver samples from each treatment were immediately fixed in Alfac solution (70\% ethanol, 5\% glacial acetic acid, and $4 \%$ formaldehyde) for $16 \mathrm{~h}$, dehydrated in a graded series of ethanol, and embedded in Paraplast Plus ${ }^{\circledR}$ (Sigma). Sections of $5 \mu \mathrm{m}$ were obtained, stained with hematoxylin/eosin and observed at 40 objective magnification in a light microscope.

Histopathological alterations index (HAI) scores were semi-quantitatively calculated using the method described by Poleksic and Mitrovic-Tutundic (1994). Indices based on the severity of lesions were used to asses liver tissue changes: $\mathrm{I}=\Sigma \mathrm{I}+10 \Sigma \mathrm{II}+100 \Sigma$ III, where stages I, II, and III correspond to the degree of the lesion. The final Index is described as follows: normal liver function ( $\mathrm{I}=$ $0-10)$, mild to moderate damage $(\mathrm{I}=11-20)$, moderate to the severe damage $(\mathrm{I}=21-50)$, severe damage ( $\mathrm{I}=$ 51-100), and irreparable damage (I > 100).

\section{Comet assay in erythrocytes}

We quantified the DNA damage in erythrocytes using the comet assay as described by Singh et al. (1988), and modified by Silva et al. (2000). Two comet microscope slides for ten fish from each treatment were prepared with standard melting agarose (1.5\% normal melting agarose prepared in phosphate-buffer saline [PBS]) and dried overnight. Five microliters of whole fish blood were mixed with $0.75 \%$ low melting point agarose at 5\% ratio (Gibco, Brazil) at $37{ }^{\circ} \mathrm{C}$ and immediately poured on pre-covered slides. Each slide was covered with a coverslip until the agarose solidified and then gently removed. Slides were placed in a lysis solution consisting of high salts and detergents $(2.5 \mathrm{M} \mathrm{NaCl}, 100 \mathrm{mM}$ EDTA, $10 \mathrm{mM}$ Tris, $\mathrm{pH}$ $10-10.5 ; 1 \%$ Triton X-100 and 10\% DMSO). Before electrophoresis, the slides were incubated for $20 \mathrm{~min}$ in alkaline electrophoresis buffer $(300 \mathrm{mM} \mathrm{NaOH}$ and $1 \mathrm{mM}$ EDTA, $\mathrm{pH}>13$ ) to produce single-stranded DNA. After alkaline-unwinding, the single-stranded DNA was electrophoresed in the gels in a dark place under alkaline conditions for $20 \mathrm{~min}$ at $300 \mathrm{~mA}$ and $25 \mathrm{~V}$ at $4{ }^{\circ} \mathrm{C}$ to produce the comets. After electrophoresis, the slides were rinsed with a suitable buffer ( $0.4 \mathrm{M}$ Tris buffer, $\mathrm{pH} 7.5)$ to neutralize the alkalis in the gels. Finally, DNA was revealed with silver solution staining ( $5 \%$ sodium carbonate, $0.1 \%$ ammonia nitrate, $0.1 \%$ silver nitrate, $0.25 \%$ tungstosilicic acid and $0.15 \%$ formaldehyde). Slides were examined using a light microscope (Leica DM 500) at 40 objective magnification. Randomly selected cells (100 cells from each of two replicate slides) were analyzed for each animal. We used the tail sizes to score the comet assay into five classes (from undamaged (zero) to maximum damage (four)). An overall score was obtained by addition of all cell scores from completely undamaged (sum zero) to maximum damage (sum 400), according to Kobayashi et al. (1995).

\section{Isolation of total RNA and cDNA synthesis}

Isolation of total RNA from four tambaqui liver from each treatment group followed the TRIzol ${ }^{\circledR}$ reagent protocol (Invitrogen) according to the manufacturer's instructions. Contaminating genomic DNA was removed using DNase I (Invitrogen).

First strand cDNA was reverse-transcribed from the total RNA using RevertAid H Minus First Strand cDNA Synthesis kit (Fermentas), and following the manufacturer's instructions. Enzymatic treatment with reverse transcriptase (MMLV Reverse Transcriptase) (200 U/ $\mu \mathrm{L}$, USB) was first done, and then mixed in a $0.2 \mathrm{~mL}$ microtube with approximately $25 \mu \mathrm{g}$ RNA, $1 \mu \mathrm{L}$ of Oligo(dT) 18 primer $(1 \mu \mathrm{g}), 1.0 \mu \mathrm{L}$ dNTP mix $(10 \mathrm{mM})$, MMLV buffer $5 \mathrm{X}$, and deionized water for a $20 \mu \mathrm{L}$ final volume. This solution was incubated at $37^{\circ} \mathrm{C}$ for $1 \mathrm{~h}$ for conversion and at $70{ }^{\circ} \mathrm{C}$ for $10 \mathrm{~min}$ to inactivate the enzyme.

\section{Determination of ras and hif-1 $\alpha$ sequences}

Degenerate primers were designed based on the conserved regions of $28 S$ (Vásquez, 2009), ef-1 $\alpha$, ras and hif- $1 \alpha$ genes described in the NCBI database for other fish species. We used these primers to obtain partial fragments of tambaqui ras and hif-1 $\alpha$ cDNAs. PCR amplification was performed using PCR Master Mix (Promega). All PCR products were sequenced with ABI PRISM ${ }^{\circledR}$ BigDye $^{\text {TM }}$ Terminator Cycle Sequencing Ready Reaction kit (Applied Biosystems) and run on an ABI 3130XL automatic DNA sequencer (Applied Biosystems). The sequences were analyzed using the BLAST program from NCBI and then used to design the specific primers for Colossoma macropomum q-PCR: ras, hif- $1 \alpha$ (target primers), $28 S$ and ef- $1 \alpha$ (reference primers) shown in Table 1.

\section{Quantitative real-time PCR}

A ViiA $^{\mathrm{TM}} 7$ Dx system (Applied Biosystems) was used as a platform to quantify gene transcripts by real-time PCR. We analyzed four samples C. macropomum liver for each treatment. The reaction mixture consisted of $1 \mu \mathrm{L}$ of cDNA as template (added in triplicate to the wells of a 96-well thin-wall PCR plate), $1 \mu \mathrm{L}$ of each primer (concentration of ras: 2 pmol; hif-1 $\alpha$ : 2 pmol, 28S: 2.5 pmol and ef- $1 \alpha$ : $1.5 \mathrm{pmol}$ ), $2 \mu \mathrm{L}$ of nuclease-free water 192 (Ambion, Life Technologies) and $5 \mu \mathrm{L}$ of SYBR Green PCR Master Mix (Applied Biosystems) in a total volume of $10 \mu \mathrm{L}$. The PCR protocol was: $2 \mathrm{~min}$ at $50^{\circ} \mathrm{C}$ and $95^{\circ} \mathrm{C}$ for $10 \mathrm{~min}$, followed by 40 cycles of $95^{\circ} \mathrm{C}$ for $15 \mathrm{~s}$ and $60^{\circ} \mathrm{C}$ for $1 \mathrm{~min}$ (annealing temperature of all primers). By melting curve analysis the presence of a single product-specific melting temperature was confirmed: $28 S$ (slope $-3.36 / \mathrm{R}^{2} 0.99$ ), ef-1 $\alpha$ (slope -.3.34/ $\mathrm{R}^{2} 0.99$ ), ras (slope $-3.33 / \mathrm{R}^{2} 0.97$ ) and 
Table 1 - Details of primers designed for reference genes $(28 S$ and $e f-1 \alpha)$ and the two target genes (ras and hif-1 $\alpha)$.

\begin{tabular}{|c|c|c|c|c|c|}
\hline Gene Symbol & $\begin{array}{l}\text { Primer sequence }\left(5^{\prime}-3^{\prime \prime}\right) \\
\text { forward/reverse }\end{array}$ & Length (bp) & Amplicon length (bp) & $\operatorname{Tm}$ & $\operatorname{Eff}(\%)^{\mathrm{a}}$ \\
\hline $28 S-F^{b}$ & CGGGTTCGTTTGCGTTAC & 18 & 150 & 54.5 & 98.19 \\
\hline $28 S-R^{b}$ & AAAGGGTGTCGGGTTCAGAT & 20 & 150 & 56.3 & 98.19 \\
\hline$E F-1 \alpha F$ & GTTGGTGAGTTTGAGGCTGG & 20 & 78 & 60.7 & 99.09 \\
\hline$E F-1 \alpha R$ & CACTCCCAGGGTGAAAGC & 18 & 78 & 60.9 & 99.09 \\
\hline Ras-F & CCAGTACATGAGGACAGGAG & 20 & 134 & 60.3 & 99.31 \\
\hline Ras-R & CAAGCACCATTGGCACATCG & 20 & 134 & 60.3 & 99.31 \\
\hline$H I F-1 \alpha F$ & CTTCTGAGCTCTGATGAGGC & 20 & 98 & 60.1 & 105.24 \\
\hline$H I F-1 \alpha R$ & GAAAGCACCATCAGGAAGCC & 20 & 98 & 61.2 & 105.24 \\
\hline
\end{tabular}

a. Primer efficiency

b. Vásquez (2009)

hif-1 $\alpha$ (slope -3.20/ $\mathrm{R}^{2}$ 0.99). Amplification efficiency for each primer set was calculated from a serial dilution curve obtained from a pool of experimental samples (1000 to $1 \mathrm{ng}$ cDNA concentration; $n=4)$. All primer pairs showed high PCR efficiency (between 98-105\%). Serial dilutions of a cDNA standard were amplified in each run to determine amplification efficiency according to Pfaffl (2001).

\section{Statistical analysis}

All data are reported as mean \pm SEM (standard errors of means). Gene expression, histopathology and comet assay data were analyzed by one-way analysis of variance (ANOVA) to assess differences between the treatment and control groups. When the data violated the premises of one-way ANOVA test, a Kruskal-Wallis one-way analysis of variance or rank test was applied. Statistical significance was accepted at the level of $p<0.05$. Statistical analysis was performed using the statistical program Sigma Stat 3.5.

\section{Results}

The liver of C. macropomum has a similar morphological structure as that of other fish species, as observed in liver slides from the group control. This group exhibited mild to moderate damage, according to the histopathological analyses classification (Figure 1A) (Poleksic and Mitrovic-Tutundic, 1994). A healthy liver presents polygonal hepatocytes with very prominent central nuclei. Hepatocytes are arranged into two-cell thick cords surrounded by sinusoidal epithelial cells (Figure 1B) (Genten et al., 2009). Damage in fish groups exposed to 8, 16, and 32 $\mu \mathrm{mol} / \mathrm{kg}$ of $\mathrm{BaP}$ were irreparable, according to the HAI classification (Poleksic and Mitrovic-Tutundic, 1994).

We observed cytoplasm vacuolization, cell hypertrophy, nuclei hypertrophy, and parenchyma disorganization in all treatments with B[a]P (Figure 1). Severe cytoplasm vacuolization occurred in the liver of fish exposed to 32 $\mu \mathrm{mol} / \mathrm{kg}$ B[a]P: small vacuoles appeared in the cellular cytoplasm and subsequently fused to form a larger vacuole.
As a consequence, the cell vacuoles forced cytoplasm and nuclei to the periphery of the cell. We also observed infiltration of leucocytes as an inflammatory sign in all exposed fish. Altered hepatocytes presented cytoplasm degeneration accompanied by an alteration in shape and size, losing their characteristic polyhedral shape and frequently showing hypertrophy (Figure 1F). Plasmatic membrane rupture was common in fish exposed to 8,16 , and $32 \mu \mathrm{mol} / \mathrm{kg}$ $\mathrm{B}[\mathrm{a}] \mathrm{P}$. These groups also presented focal necrosis in almost all animals (Figure 1D).

Observing the HAI index described by Poleksic and Mitrovic-Tutundic (1994), the occurrence of liver damage was evident in fish exposed to the higher $\mathrm{B}[\mathrm{a}] \mathrm{P}$ concentrations; 8,16 , and $32 \mu \mathrm{mol} / \mathrm{kg} \mathrm{B}[\mathrm{a}] \mathrm{P}(\mathrm{HAI}=142.80 \pm 2.6$, $146.16 \pm 3.09$, and 102.16 \pm 20.89 , respectively) (Figure 2).

Genetic damage as measured through the comet assay was induced in the acute experiment $(96 \mathrm{~h})$ with $\mathrm{B}[\mathrm{a}] \mathrm{P}$. Exposure to $\mathrm{B}[\mathrm{a}] \mathrm{P}$ caused a significant genotoxic effect in $C$. macropomum exposed to $8(\mathrm{GDI}=264 \pm 5.66)$ and 16 $\mu \mathrm{mol} / \mathrm{kg}(\mathrm{GDI}=266 \pm 27.31)$, in comparison with control. No difference was found in fish exposed to $32 \mu \mathrm{mol} / \mathrm{kg}$ $\mathrm{B}[\mathrm{a}] \mathrm{P}(112.35 \pm 12.16)$ compared to the control group (Figure 3).

An increase was observed in the expression of ras oncogene in C. macropomum exposed for $96 \mathrm{~h}$ to 4,8 and $16 \mu \mathrm{mol} / \mathrm{kg} \mathrm{B}[\mathrm{a}] \mathrm{P}$ in comparison to the control (Figure 4). Ras oncogene was overexpressed 4.96-fold in fish exposed to $4 \mu \mathrm{mol} / \mathrm{kg}$ of $\mathrm{B}[\mathrm{a}] \mathrm{P}, 7.10$-fold in fish exposed to 8 $\mu \mathrm{mol} / \mathrm{kg}$ and 6.78 -fold in fish exposed to $16 \mu \mathrm{mol} / \mathrm{kg}$ of $\mathrm{B}[\mathrm{a}] \mathrm{P}$. There was no difference in the expression of ras in the $32 \mu \mathrm{mol} / \mathrm{kg} \mathrm{B}$ [a]P group compared to the control group.

The expression of hif-1 $\alpha$ increased approximately 8.82-fold in fish injected with $4 \mu \mathrm{mol} / \mathrm{kg} \mathrm{B}[\mathrm{a}] \mathrm{P}$ and approximately 4.64-fold in fish injected with $8 \mu \mathrm{mol} / \mathrm{kg} \mathrm{B}[\mathrm{a}] \mathrm{P}$ in comparison with the control group (Figure 5). However in the higher concentration of $\mathrm{B}[\mathrm{a}] \mathrm{P}(16$ and $32 \mu \mathrm{mol} / \mathrm{kg}$ ), the expression of hif-1 $\alpha$ was similar with the control group. 


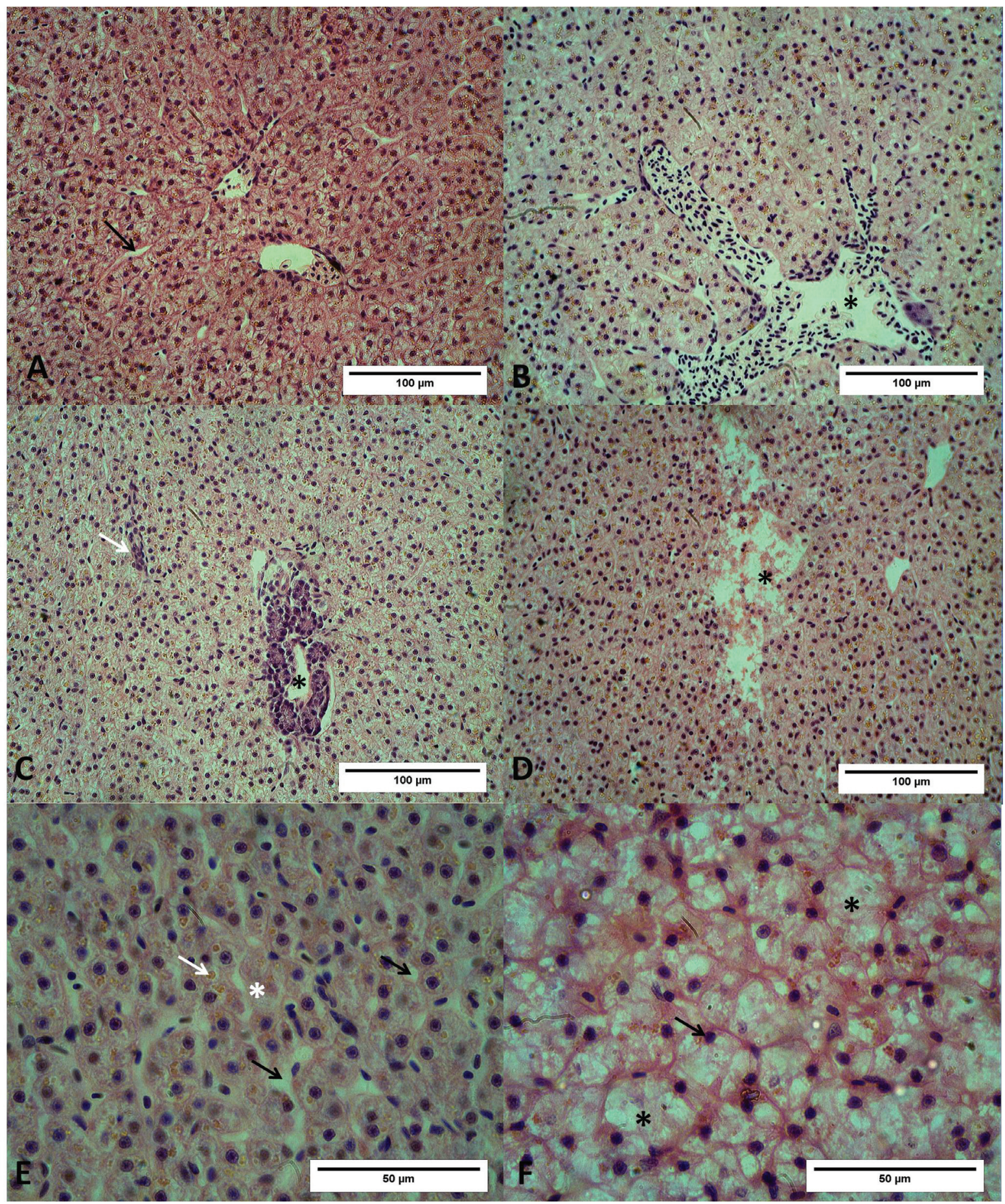

Figure 1 - C. macropomum liver exposed to corn oil (control group) or doses of B[a]P. (A) Normal liver, hepatocytes are organized in one or two layers surrounded by sinusoids (black arrows). (B) Normal liver parenchyma, highlighting a blood vessel with red blood cells (asterisk). (C) Image of liver exposed to $8 \mu \mathrm{mol} / \mathrm{kg} \mathrm{B}$ [a] P evidencing a hepatopancreas (asterisk) and sinusoid obstruction (white arrow). (D) Image of fish liver exposed to $8 \mu \mathrm{mol} / \mathrm{kg}$ $\mathrm{B}[\mathrm{a}] \mathrm{P}$, showing necrotic area (asterisk). (E) Image of liver exposed to $16 \mu \mathrm{mol} / \mathrm{kg} \mathrm{B}[\mathrm{a}] \mathrm{P}$ showing some hepatocytes without nucleus (white asterisk), sinusoidal dilatation (black arrows) and hemosiderin (white arrow). (F) Image of vacuolated hepatocytes of fish exposed to $32 \mu \mathrm{mol} / \mathrm{kg}$ B[a]P; cytoplasm degeneration (black asterisks) and pyknotic nuclei (black arrow) are evident. Slides were stained with hematoxylin and eosin.

\section{Discussion}

Histopathological liver damage caused by exposure to $\mathrm{B}[\mathrm{a}] \mathrm{P}$ and petroleum derivatives are largely described in the literature (Malmstrom et al., 2004, Costa et al., 2010, Agamy, 2012, Moller et al., 2014). Liver is one of the most important organs to be addressed, since it is responsible for the detoxification process in the organism, and it is the pri- 


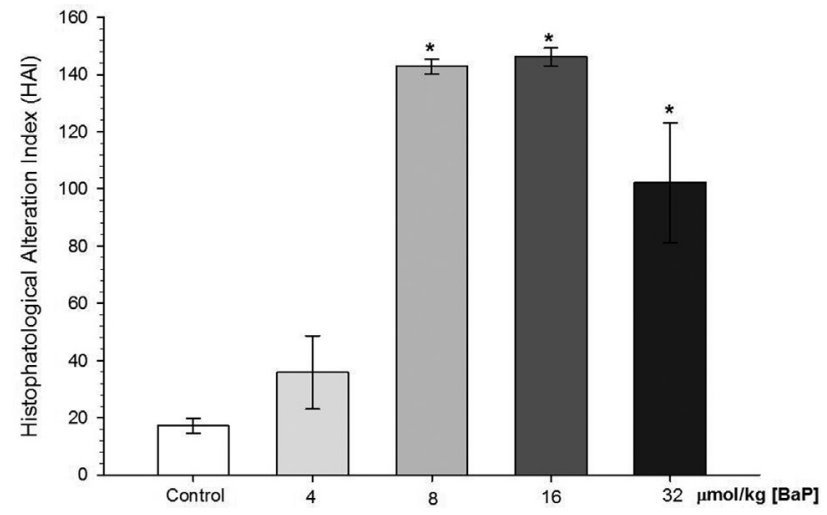

Figure 2 - Histopathological alteration index (HAI) of C. macropomum liver after exposure to different concentrations of $\mathrm{B}[\mathrm{a}] \mathrm{P}$. Indexes are in accordance with Poleksic and Mitrovic-Tutundic (1994). *Indicates significant differences compared to control group (corn oil) $(\mathrm{p}<0.05)$. Kruskal-Wallis test was used.

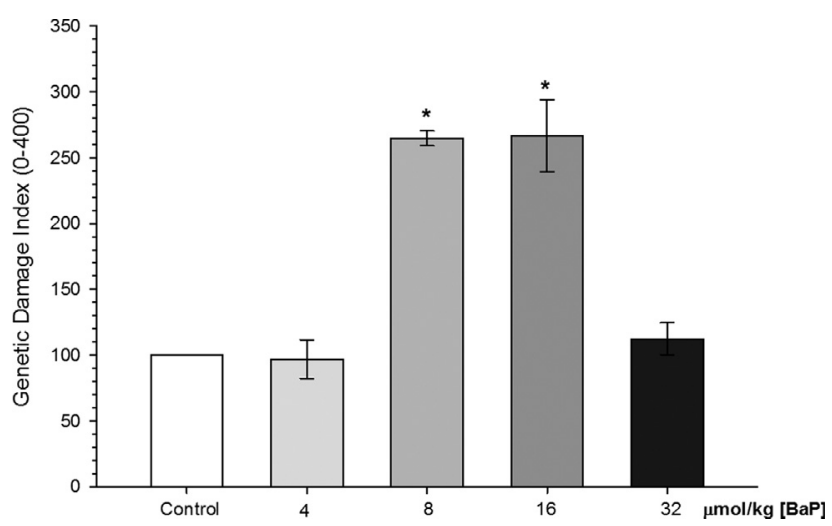

Figure 3 - Genetic damage index (GDI) of erythrocytes of $C$. macropomum after $96 \mathrm{~h}$ of injection of different concentrations of $\mathrm{B}[\mathrm{a}] \mathrm{P}$. *Indicates significant differences compared to control group (corn oil) (p $<0.05)$. Kruskal-Wallis test was used.

mary organ in the biotransformation of organic xenobiotics (Health, 1995, Hinton et al., 2001, Rojo-Nieto et al., 2014).

Many investigations have shown that focal, multifocal and diffuse vacuolar degeneration of hepatocytes are the result of fish exposure to a variety of different carcinogenic agents (Couch, 1975, Mathur, 1975, Stehr et al., 1998, Nero et al., 2006, Stentiford et al., 2014). We also detected cell hypertrophy, followed by loss of polyhedral shape, inflammatory focus with leucocytes infiltration, cytoplasmic degeneration, and parenchyma disorganization in these fish. Agamy (2012) described hepatocytes with marked nuclear enlargement and moderate cellular enlargement, along with an alteration in shape and size, losing their typical polyhedric shape and frequently presenting hypertrophy in the liver of juvenile rabbit fish exposed to the oil water accommodated fraction (WAF). Malmstrom et al. (2004) also verified a massive infiltration of inflammatory cells in rainbow trout (Oncorhynchus mykiss) and cytoplas-

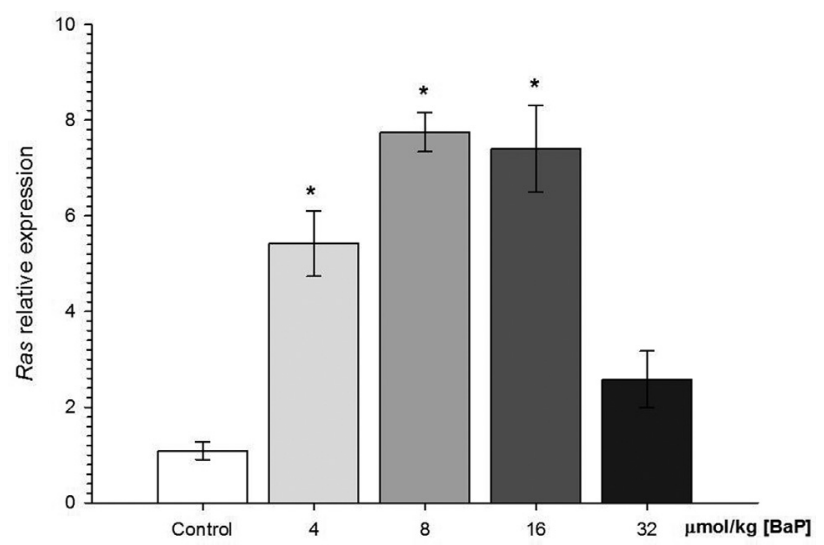

Figure 4 - Relative expression of the oncogene ras in liver of $C$. macropomum after $96 \mathrm{~h}$ of injection of different concentrations of B[a]P. *Indicates significant difference in comparison to control group ( $\mathrm{p}<$ $0.05)$. Kruskal-Wallis test was used.

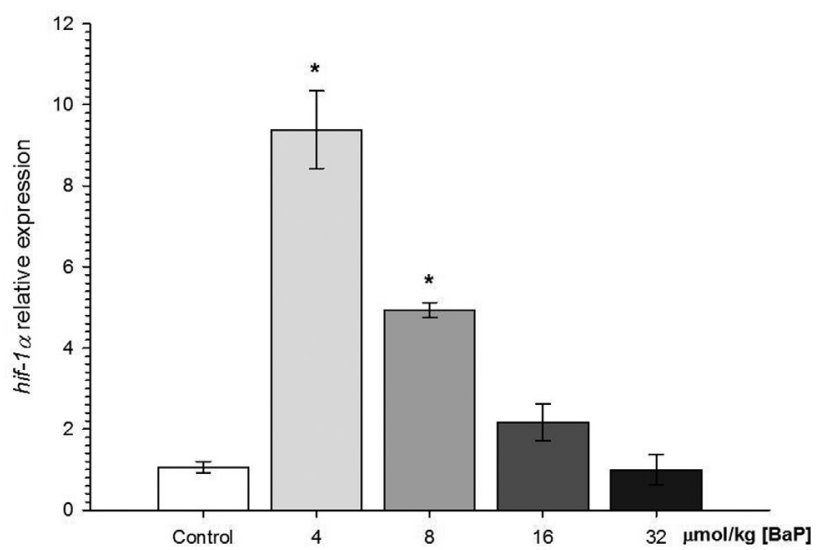

Figure 5 - Relative expression of gene hif- $1 \alpha$ gene in C. macropomum after $96 \mathrm{~h}$ of injection of different concentrations of B[a]P. *Indicates significant difference in comparison to control group (corn oil) $(\mathrm{p}<0.05)$. Kruskal-Wallis test was used.

mic vacuolization in flounder (Platichthys flesus) intraperitoneally injected with $\mathrm{B}[\mathrm{a}] \mathrm{P}$. Multifocal inflammatory lesions in the liver were recognized in other two teleosts, Atlantic cod (Gadus morhua) and flounder (Platichthys flesus), caged for three months on contaminated sediments in a Norwegian fjord (Husoy et al., 1996). In the present work, liver histopathology of C. macropomum exposed to different concentrations of $\mathrm{B}[\mathrm{a}] \mathrm{P}$ revealed an increase in tissue injuries in a dose-dependent way. In all treatments, we could observe cellular vacuolization, as was also observed in the liver of juvenile rabbit fish (Siganus canaliculatus) exposed to a WAF of light Arabian crude oil (Agamy, 2012). Liver hepatic parenchyma disorganization appears to be correlated with PAH exposure (Rojo-Nieto et al., 2014). In our study, the lesions observed in $C$. macropomum liver were associated with PAH injection, indicating the extreme toxic potential of this compound to aquatic animals. These lesions were more evident in focal 
necrosis of hepatocytes, observed in most of the $C$. macropomum livers after treatment with B[a]P. Agamy (2012), studying rabbit fish (Siganus canaliculatus) exposed to dispersed oil for six days, found hepatocyte necrosis and cellular swelling on fish liver, which became larger with increased time of exposure. In another study with eelpout (Zoarces viviparus) collected in differently polluted areas, necrosis and degeneration were observed and the cellular structure was no longer maintained, with eosinophilic cytoplasm elements and free pyknotic nuclei being visible within the liver sections (Fricke et al., 2014). As observed in the present work, Abdel-Moneim et al. (2012) also described foci of local hepatic tissue necrosis characterized by entirely destroyed hepatic tubules and, in most cases, no remaining hepatic cellular structure. In our study, we observed that some fish also contained lysed hepatocyte remnants. Thus, we suggest that acute exposure to this pollutant induced liver damage that impairs normal liver function in these animals.

The analysis of DNA damage in aquatic organisms has been considered a highly suitable method for evaluating genotoxicity caused by contamination of environments. In general, the comet assay method is considered advantageous because it detects and quantifies the genotoxic impact without requiring a detailed knowledge of the identity or the physical/chemical properties of the contaminants (Frenzilli et al., 2009). Numerous studies evidenced DNA strand break using the comet assay in different animal models (Lemiere et al., 2005, Lacaze et al., 2010, Michel et al., 2013). In this study, the comet assay indicated DNA damage in C. macropomum blood cells of fish injected with 8 and $16 \mu \mathrm{mol} / \mathrm{kg} \mu \mathrm{M} \mathrm{B}[\mathrm{a}] \mathrm{P}$ in comparison with the control. There was no difference among groups injected with corn oil, 4 and $32 \mu \mathrm{mol} / \mathrm{kg} \mathrm{B}$ [a]P. This can be explained by the release of new erythrocyte cells due to the high concentration of the pollutant, which puts a high cost on the individual's defense system. Also, mechanisms of DNA repair in erythrocytes may have been activated. Our results are similar to those of Jeong et al. (2015). These authors examined the degree of DNA damage in beakfish (Oplegnathus fasciatus) caused by three fractions (aliphatic hydrocarbons, aromatic hydrocarbons, and polar compounds) of sediment organic extracts taken from Taean (Korea). The DNA damage level was the highest in cells exposed to 1.00 $\mathrm{mg} / \mathrm{g}$ dry weight (dw) followed by the $1.09 \mathrm{mg} / \mathrm{g} \mathrm{dw}$ and $0.72 \mathrm{mg} / \mathrm{g} \mathrm{dw}$ to PAH. Studying DNA damage in gill and liver of carp and rainbow trout, Kim and Hyun (2006) observed similar results. In their study, the level of damage was very low during the initial $24 \mathrm{~h}$ of exposure to $\mathrm{B}[\mathrm{a}] \mathrm{P}$ and increased dramatically during the next $24 \mathrm{~h}$, and then gradually decreased until $96 \mathrm{~h}$. Curtis et al. (2011) observed the same result in rainbow trout exposed to $\mathrm{B}[\mathrm{a}] \mathrm{P}$, where damage to blood cell DNA increased in fish fed a diet contaminated with $\mathrm{B}[\mathrm{a}] \mathrm{P}$ after 14 and 28 days compared to controls. In our study, the DNA damage in fish injected with an intermediary concentration of $\mathrm{B}[\mathrm{a}] \mathrm{P}$ was higher. Future investigation concerning DNA repair mechanisms should help to understand the decrease in DNA damage in fish injected with higher amounts of $\mathrm{B}[\mathrm{a}] \mathrm{P}$.

Another way to evaluate the effects of certain pollutants as carcinogenic inducers is through the alteration in gene expressions or mutations (Ostrander and Rotchell, 2005). The oncogene ras is considered one of the most important genes involved in carcinogenesis. The characterization of this gene in several fish species and the presence of ras mutations have already been described in fish populations inhabiting hydrocarbon contaminated areas and following experimental exposure to specific contaminants (Nogueira et al., 2006). In the present study, the ras oncogene was found overexpressed in livers of fish treated with 4,8 , and $16 \mu \mathrm{mol} / \mathrm{kg} \mathrm{B}[\mathrm{a}] \mathrm{P}$. When comparing these data with DNA damage in erythrocytes, significant differences in DNA damage were apparent only at concentrations of 8 and $16 \mu \mathrm{mol} / \mathrm{kg}$ of $\mathrm{B}[\mathrm{a}] \mathrm{P}$. Our data suggest that the oncogene ras is expressed even with exposure to low concentrations of the contaminant, and DNA damage is more significant when animals are subjected to higher concentrations. However, in fish injected with the 8 and $16 \mu \mathrm{mol} / \mathrm{kg}$ concentrations, DNA damage and ras oncogene expression responded similarly to the presence of the contaminant. Nogueira et al. (2010), studying Dicentrarchus labrax and Liza aurata in a contaminated coastal lagoon polluted by $\mathrm{PAH}$, observed no differences in the expression levels of ras oncogene among fish from different sites. Similar results were found in Anguilla anguilla exposed to 0.1 and $0.3 \mu \mathrm{M} \mathrm{B}[\mathrm{a}] \mathrm{P}$, where the analysis of ras oncogene revealed no differences in levels of expression between control and exposed fish (Nogueira et al., 2006). In another study with mussels (Mytilus galloprovincialis) collected in sites with different levels of petrochemical contamination along the NW coast of Portugal, the expression of ras oncogene in digestive gland and gonads was decreased in PAH-contaminated animals. These authors also found similar results in fish exposed to $100 \%$ WAF (Lima et al., 2008). According to Rotchell et al. (2001), the pattern and incidence of ras oncogene mutations in environmentally induced tumors also appear to be species-specific in fish. Tumors were not observed in tissue liver analyses in this study due to the short exposure period, but the described histopathology characteristics may certainly lead to tumor formation as an inflammatory focus with longer exposure to the pollutant B [a]P (Grivennikov et al., 2010). Additionally, overexpression of the oncogene ras observed herein is among the mechanisms that implicate carcinogenesis (Nogueira et al., 2006).

Another gene related with cancer is hif-1 $\alpha$, which has been identified as a key regulator of angiogenesis, inflammation and anaerobic metabolism (Dehne and Brune, 2009). Importantly in the past few years, hif- $1 \alpha$ has been 
implicated in the development of a range of liver pathologies, such as liver fibrosis, activation of the immune system, hepatocellular carcinoma, and others, in humans, as well as in rodents (Nath and Szabo, 2012, Semenza, 2012). In humans, many studies have emphasized the metastasis process in solid tumors induced by the expression of hif- $1 \alpha$ (Schweiki et al., 1992, Melstrom et al., 2011). Most hypoxia studies have been focused on mammalian systems (Taylor and Sivakumar, 2005). However, hypoxia is a common phenomenon also for fish. In fish, the majority of studies describe the expression of hif- $1 \alpha$ in hypoxic environmental condition, but not considering the combined effects of hypoxia and pollution (Terova et al., 2008).

In the present study, hypoxia was not a challenge to C. macropomum, but the challenge was the contaminant $(\mathrm{B}[\mathrm{a}] \mathrm{P})$. The highest expression of hif- $1 \alpha$ occurred at the lowest concentration of $\mathrm{B}[\mathrm{a}] \mathrm{P}$, suggesting that the hepatocytes were capable of activating the transcription of this gene, helping to maintain the cell survival machinery, as evidenced by the literature, which correlates hif-1 $\alpha$ with cell proliferation and survival (Siddiq et al., 2007). In fish exposed to the highest concentration of $\mathrm{B}[\mathrm{a}] \mathrm{P}$, the cellular machinery was already compromised by cell damage, and the tissue was not efficient in controlling gene expression to keep levels of hif-1 $\alpha$ high, since the normal functioning of the liver was impaired by necrosis. Yu et al. (2008) suggested that the application of xenobiotics such as B[a]P to hypoxia-stressed fish induces the increase in HIF-1-mediated transcription, particularly in xenobiotic-metabolizing organs such as the liver. The orange-spotted grouper (Epinephelus coioides) was examined upon single and combined exposures to hypoxia and $\mathrm{B}[\mathrm{a}] \mathrm{P}$. The responses for four hypoxia-responsive (HIF-1-mediated) genes [igfbp (insulin-like growth factor binding protein), epo (erythropoietin), ldh-a (lactate dehydrogenase an isoform) and vegf (vascular endothelial growth factor)] in fish liver tissues were monitored at four different time intervals using realtime qPCR. The authors showed that $\mathrm{B}[\mathrm{a}] \mathrm{P}$ did not alter the expression of these four genes throughout the course of the exposure to normoxic conditions. Although when combined with hypoxia, the pollutant caused the activation of these genes at some concentrations. Under hypoxia, these genes were very responsive. In fact, the hif-1 $\alpha$ gene encodes a transcription factor controling more than 100 genes, including genes responsible for immune processes and inflammation of cells (Yu et al., 2008).

As far as we know, this is the first study that analyses in combination the responses of the ras and hif- $1 \alpha$ genes in a Neotropical freshwater fish (C. macropomum) under acute exposure to $\mathrm{B}[\mathrm{a}] \mathrm{P}$ at normoxic conditions. Both gene expression and comet assay analyses showed full bellshaped dose-response results. We observed an increase in gene expression and erythrocyte DNA damage in fish exposed to 4,8 and $16 \mu \mathrm{mol} / \mathrm{kg} \mathrm{B}[\mathrm{a}] \mathrm{P}$, and a decrease of these responses in fish exposed to the highest concentration (32 $\mu \mathrm{mol} / \mathrm{kg} \mathrm{B}[\mathrm{a}] \mathrm{P})$. Bosveld et al. (2002) showed response to PAHs in their study with ethoxyresorufin dealkylase (EROD) activity in the H4IIE rat hepatoma in an in vitro bioassay. These authors observed that a category of compounds such as indeno[1,2,3-cd]pyrene (IP), benz[a]anthracene $(\mathrm{BaA}), \mathrm{B}[\mathrm{a}] \mathrm{P}$, chrysene $(\mathrm{Chr})$, and benzo[k]fluoranthene $(\mathrm{BkF})$, induces strong reactions, showing full bell-shaped dose-response relationships over a wide dose range and with a strong increase in EROD activity. Lu et al. (2009) also observed bell-shaped dose-response in their study with Carassius auratus exposed to the PAH indeno[1,2,3-cd]pyrene via intraperitoneal injection at dosages of $0.1,1,2,5$ and 10 (or 8 ) $\mathrm{mg} / \mathrm{kg}$. The EROD activity resulted in a decreased fold-induction at the highest dosage of indeno[1,2,3-cd]pyrene $(10 \mathrm{mg} / \mathrm{kg})$, as well as glutathione S-transferase, which showed the same behavior. Bellshaped curves have been reported for various in vitro and in vivo systems after exposure to PAHs (Kennedy et al., 1996, Delesclue et al., 1997).

The majority of the works addressing ras oncogenes are done in humans (Maertens and Cichowski, 2014). The studies with hif- $1 \alpha$ also describe the expression of this gene in human solid tumors, and in metastasis (Fraga et al., 2009). In fish species, many authors study this gene as a marker for environmental hypoxia condition without a pollutant (Rissanen et al., 2006, Rimoldi et al., 2012). Ongoing studies in our laboratory combining pollutants and hypoxia exposure and exposure to different climate scenarios should further help to respond how these genes respond to synergistic effects.

\section{Conclusion}

Amazonian fish have proven to be versatile as bioindicators of environmental pollution, using both toxicology and genotoxicity markers. In the present work, we observed that the species C. macropomum is sensible to $\mathrm{B}[\mathrm{a}] \mathrm{P}$ under acute exposure. However, further studies are necessary to better understand the behavior of the ras and hif- $1 \alpha$ genes under the effects of contaminants. The exposure of this species to this pollutant for a longer time and along with other environmental stresses is under development. This work contributed with essential data to further understand the role of these genes in the cell machinery, especially when a contaminant is involved. The mechanisms related in the overexpression of ras and hif-1 $\alpha$ genes on the intermediary concentration of $\mathrm{B}[\mathrm{a}] \mathrm{P}$ needs further study.

\section{Acknowledgments}

FAPEAM and CNPq financially supported this study through INCT-ADAPTA. We thank Carolina Dultra Abrahim for her assistance in the comet assay analyses. Thanks are also due to the personnel of the Functional Histology Laboratory of the Federal University of Amazonas 
for their support with the preparation of histological material.

\section{References}

Abdel-Moneim AM, Al-Kahtani MA and Elmenshawy OM (2012) Histopathological biomarkers in gills and liver of Oreochromis niloticus from polluted wetland environments, Saudi Arabia. Chemosphere 88:1028-1035.

Agamy E (2012) Histopathological liver alterations in juvenile rabbit fish (Siganus canaliculatus) exposed to light Arabian crude oil, dispersed oil and dispersant. Ecotoxicol Environ Saf 75:171-179.

Bailey GS, Selivonchick D and Hendricks J (1987) Initiation, promotion, and inhibition of carcinogenesis in rainbow trout. Environ Health Persp 71:147-153.

Bailey GS, Williams DE and Hendricks JD (1996) Fish models for environmental carcinogenesis. Environ Health Persp 104(Suppl 1):5-21.

Bosveld ATC, de Bie PAF, van den Brink NW, Jongepier H and Klomp AV (2002) In vitro EROD induction equivalency factors for the 10 PAHs generally monitored in risk assessment studies in The Netherlands. Chemosphere 49:75-83.

Buhler DR and Williams DE (1989) Enzymes involved in metabolism of PAH by fish and other aquatic animals: Oxidative enzymes (or phase I enzymes). In: Varanasi U (ed) Metabolism of Polycyclic Aromatic Hydrocarbons in the Aquatic Environment. CRC Press, Boca Raton, pp 151-184.

Cheng R, Bradford S, Barnes D, Williams D, Hendricks J and Bailey G (1997) Cloning, sequencing and embryonic expression of an N-ras proto-oncogene isolated from an enriched zebrafish (Danio rerio) cDNA library. Mol Mar Biol Biotechnol 6:40-47.

Conney AH, Chang RL, Jerina DM and Wei SJ (1994) Studies on the metabolism of benzo[a]pyrene and dose-dependent differences in the mutagenic profile of its ultimate carcinogenic metabolite. Drug Metab Rev 26:25-163.

Costa PM, Chicano-Gálvez E, López Barea J, DelValls TA and Costa MH (2010) Alterations to proteome and tissue recovery responses in fish liver caused by a short term combination treatment with cadmium and benzo[a]pyrene. Environ Pollut 158:3338-3346.

Couch JA (1975) Histopathological effects of pesticides and related chemicals on the livers of fishes. In: Ribelin WE and Migaki G (eds) The Pathology of Fishes. The University of Wisconsin Press, Madison, pp 559-584.

Curtis LR, Garzon CB, Arkoosh M, Collier T, Myers MS, Buzitis J and Hahn ME (2011) Reduced cytochrome P4501A activity and recovery from oxidative stress during subchronic benzo[a]pyrene and benzo[e]pyrene treatment of rainbow trout. Toxicol Appl Pharmacol 254:1-7.

Dehne N and Brüne B (2009) HIF-1 in the inflammatory microenvironment. Exp Cell Biol 315:1791-1797.

Delesclue C, Ledirac N, de Sousa G, Pralvorio M, Botta-Fridlund D, Letreut Y and Rahmani R (1997) Comparative study of CYP1A1 induction by 3-methylcholanthrene in various human hepatic and epidermal cell types. Toxicol In Vitro 11:443-450.

Fraga A, Ribeiro R and Medeiros R (2009) Revisión - Oncología Hipoxia tumoral. Papel del factor inducible por hipoxia. Actas Urol Esp 33:941-951.
Frenzilli G, Nigro M and Lyons BP (2009) The Comet assay for the evaluation of genotoxic impact in aquatic environments. Mutat Res 681:80-92.

Fricke NF, Stentiford G, Feist SW and Lang T (2014) Liver histopathology in Baltic eelpout (Zoarces viviparus). A baseline study for use in marine environmental monitoring. Mar Environ Res 82:1-14.

Gao M, Li Y, Sun Y, Long J, Kong Y, Yang S and Wang Y (2011) A common carcinogen benzo[a]pyrene causes p53 overexpression in mouse cervix via DNA damage. Mutat Res 724:69-75.

Geng X, Feng J, Liu S, Wang Y, Arias C and Liu Z (2014) Transcriptional regulation of hypoxia inducible factors alpha (HIF- $\alpha$ ) and their inhibiting factor (FIH-1) of channel catfish (Ictalurus punctatus) under hypoxia. Comp Biochem Physiol Part B 169:38-50.

Genten F, Terwinghe E and Dangy A (2009) Atlas of fish Histology. Science Publishers, Enfield, NH, pp 1-215.

Grivennikov SI, Greten FR and Karin M (2010) Immunity, inflammation, and cancer. Cell 140:883-899.

Grabher C and Thomas AL (2006) Fishing for cancer models. Nat Biotechnol 24:45-46.

Harris CC, Vahakangas K, Newman MJ, Trivers GT, Shamsuddin A, Sinopoli N, Mann DL and Wright WE (1985) Detection of benzo[ a]pyrene diol epoxide-DNA adducts in peripheral blood lymphocytes and antibodies to the adducts in serum from coke oven workers. Proc Natl Acad Sci U S A 82:6672-6676.

Health AG (1995) Water Pollution and Fish Physiology, vol. 2. CRC Lewis Publishers, Boca Raton, 337 pp.

Hinton DE, Segner H and Braunbeck T (2001) Toxic responses of the liver. In: Schlenk D and Benson WH (eds) Target Organ Toxicity in Marine and Freshwater Teleosts. Taylor and Francis, London, pp 224-268.

Husøy A, Myers MS and Goksøyr A (1996) Cellular localization of cytochrome P450 (CYP1A) induction and histology in Atlantic cod (Gadus morhua L.) and European flounder (Platichthys flesus) after environmental exposure to contaminants by caging in Sørfjorden, Norway. Aquat Toxicol 36:53-74.

IARC, International Agency for Research on Cancer (2012) A review of human carcinogens: Chemical agents and related occupations. In: IARC Monographs on the Evaluation of Carcinogenic Risks to Humans, vol. 100 F, pp 111-114.

Jaakkola MS and Jaakkola JJ (1997) Assessment of exposure to environmental tobacco smoke. Eur Respir J 10:2384-2397.

Jeong HJ, Lee HJ, Hong S, Khim JS, Shim WJ and Kim GB (2015) DNA damage caused by organic extracts of contaminated sediment, crude, and weathered oil and their fractions recovered up to 5 years after the 2007 Hebei Spirit oil spill off Korea. Mar Pollut Bull 95:452-457.

Kennedy SW, Lorenzen A, Jones SP, Hahn ME and Stegeman JJ (1996) Cytochrome P4501A induction in avian hepatocyte cultures: A promising approach for predicting the sensitivity of avian species to toxic effects of halogenated aromatic hydrocarbons. Toxicol Appl Pharmacol 141:214-230.

Kim II-Y and Hyun CH (2006) Comparative evaluation of the alkaline comet assay with the micronucleus test for genotoxicity monitoring using aquatic organisms. Ecotoxicol Environ Saf 64:288-297. 
Kobayashi H, Sugiyama C, Morikawa Y, Hayashi M and Sofuni T (1995) A comparison between manual microscopic analysis and computerized image analysis in the single cell gel electrophoresis assay. MMS Commun 2:103-115.

Lacaze E, Geffard O, Bony S and Devaux A (2010) Genotoxicity assessment in the amphipod Gammarus fossarum by use of the alkaline Comet assay. Mut Res 700:32-38.

Lam SH, Wu YL, Vega VB, Miller LD, Spitsbergen J, Tong Y, Zhan H, Govindarajan KR, Lee S, Mathavan S, et al. (2006) Conservation of gene expression signatures between zebrafish and human liver tumors and tumor progression. Nat Biotechnol 24:73-75.

Latimer JS and Zheng J (2003) The sources, transport, and fate of PAHs in the marine environment. In: Peter ETD (ed) Pahs: An Ecotoxicological Perspective. John Wiley \& Sons, Oxford, pp 9-34.

Lemiere S, Cossu-Leguille C, Bispo A, Jourdain M-J, Lanhers M-C, Burnel D and Vasseur P (2005) DNA damage measured by the single-cell gel electrophoresis (Comet) assay in mammals fed with mussels contaminated by the 'Erika' oil-spill. Mutat Res 581:11-21.

Lima I, Peck MR, Rendón-Von Osten J, Soares AMVM, Guilhermino L and Rotchell JM (2008) Ras gene in marine mussels: A molecular level response to petrochemical exposure. Mar Pollut Bull 56:633-640.

Lu GE, Wang E-C and Zhu Z (2009) The dose-response relationships for EROD and GST induced by polyaromatic hydrocarbons in Carassius auratus. Bull Environ Contam Toxicol 82:194-199.

Maertens O and Cichowski K (2014) An expanding role for RAS GTPase activating proteins (RAS GAPs) in cancer. Adv Biol Regul 55:1-14.

Malmstrom CM, Koponen K, Lindstrom-Seppa P and Bylund G (2004) Induction and localization of hepatic CYP4501A in flounder and rainbow trout exposed to benzo[a]pyrene. Ecotoxicol Environ Saf 58:365-372.

Mangold K, Chang YJ, Mathews C, Marien K, Hendricks J and Bailey G (1991) Expression of ras genes in rainbow trout liver. Mol Carcin 4:97-102.

Marcuschi I, Espósito TS, Machado MF, Hirata IY, Machado MF, Silva MV, Carvalho Jr LB, Oveira V and Bezerra RS (2010) Purification, characterization and substrate specificity of a trypsin from the Amazonian fish tambaqui (Colossoma macropomum). Biochem Biophys Res Commun 396:667673.

Mathur DS (1975) Histopathological changes in the liver of fishes resulting from exposure to dieldrin and lindane. Toxicology 13:109-110.

Maxwell pH (2005) The HIF pathway in cancer. Semin Cell Dev Biol 16:523-530.

Maxwell PH, Dachs GU, Gleadle JM, Nicholls LG, Harris AL, Stratford IJ, Hankinson O, Pugh CW and Ratcliffe PJ (1997) Hypoxia inducible factor- 1 modulates gene expression in solid tumors and influences both angiogenesis and tumor growth, Proc Natl Acad Sci U S A 94:8104-8109.

Meador JP, Stein JE, Reichert WL and Varanasi U (1995) Bioaccumulation of polycyclic aromatic hydrocarbons by marine organisms. Rev Environ Contam Toxicol 143:79-165.

Melstrom LG, Salabat MR, Ding X-Z, Strouch MJ, Grippo PJ, Mirzoeva S, Pelling JC, David J and Bentrem M (2011) Apigenin down-regulates the hypoxia response genes: HIF-
$1 \alpha$, GLUT-1, and VEGF in human pancreatic cancer cells. J Surg Res 167:173-181.

Michel C, Bourgeault A, Palais F, Geffard A and Vincent-Hubert F (2013) Seasonal and PAH impact on DNA strand-break levels in gills of transplanted zebra mussels. Ecotoxicol Environ Saf 92:18-26.

Moller AM, Korytar T, Kollner B, Schmidt-Posthaus H and Segner H (2014) The teleostean liver as an immunological organ: Intrahepatic immune cells (IHICs) in healthy and benzo[a]pyrene challenged rainbow trout (Oncorhynchus mykiss). Dev Comp Immunol 46:518-529.

Nath B and Szabo G (2012) Hypoxia and hypoxia inducible factors: Diverse roles in liver diseases. Hepatol 55:622-633.

Nemoto N, Kodama K, Tazawa A, Masahito P and Ishikawa T (1986) Extensive sequence homology of the goldfish ras gene to mammalian ras genes. Differentiation 32:17-23.

Nero V, Farwell A, Lister A, Van Der Kraak G, Lee LEJ, Van Meer T, MacKinnon MD and Dixon DG (2006) Gill and liver histopathological changes in yellow perch (Perca flavescens) and goldfish (Carassius auratus) exposed to oil sands process-affected water. Ecotoxicol Environ Saf 63:365-377

Nogueira PR, Lourenço J, Mendo S and Rotchell JM (2006) Mutation analysis of ras gene in the liver of European eel(Anguilla anguilla L.) exposed to benzo[a]pyrene. Mar Pollut Bull 52:1611-1616.

Nogueira P, Pacheco M, Pereira ML, Mendo S and Rotchell JM (2010) Anchoring novel molecular biomarker responses to traditional responses in fish exposed to environmental contamination. Environ Pollut 158:1783-1790.

Oliveira-Ribeiro CA, Padrós J, Valdez Domingos FX, Akaishi FM and Pelletier É (2007) Histopathological evidence of antagonistic effects of tributyltin on benzo[a]pyrene toxicity in the Arctic charr (Salvelinus alpinus). Sci Total Environ 372:549-553.

Ostrander GK and Rotchell JM (2005) Fish models of carcinogenesis. In: Mommsen TP and Moon TW (eds) Biochemistry and Molecular Biology of Fishes, vol. 6. Elsevier B.V., New York, pp 255-288.

Padrós J, Pelletier É and Ciro Oliveira Ribeiro CA (2003) Metabolic interactions between low doses of benzo[ $a]$ pyrene and tributyltin in arctic charr (Salvelinus alpinus): A long-term in vivo study. Toxicol Appl Pharmacol 192:45-55.

Pfaffl MW (2001) A new mathematical model for relative quantification in real-time RT PCR. Nucleic Acids Res 29:20032007.

Poleksic V and Mitrovic-Tutundic V (1994) Fish gills as a monitor of sublethal and chronic effects of pollution. In: Müller R and Lloyd R (eds) Sublethal and Chronic Effects of Pollutants on Freshwater Fish. Fishing News Books, Oxford, pp 339-352.

Pryor WA and Stone K (1993). Oxidants in cigarette smoke. Radicals, hydrogen peroxide, peroxynitrate, and peroxynitrite. NY Acad Sci 68:12-27.

Rimoldi S, Terova G, Ceccuzzi P, Marelli S, Antonini M and Saroglia M (2012) HIF-1a mRNA levels in Eurasian perch (Perca fluviatilis) exposed to acute and chronic hypoxia Mol Biol Rep 39:4009-4015.

Rissanen E, Tranberg HK, Sollid J, Nilsson GE and Nikinmaa M (2006) Temperature regulates hypoxia-inducible factor-1 
(HIF-1) in a poikilothermic vertebrate, crucian carp (Carassius carassius). J Exp Biol 209:994-1003.

Rojo-Nieto E, Oliva M, Sales D and Perales JA (2014) Feral finfish, and their relationships with sediments and seawater, as a tool for risk assessment of PAHs in chronically polluted environments. Sci Total Environ 470-471:1030-1039.

Rotchell MJ, Lee J, Chipman JK and Ostrander GK (2001) Structure, expression and activation of fish ras genes. Aquat Toxicol 55:1-21.

Rytkönen TK, Ryynänen HJ, Nikinmaa M and Primmer CR (2008) Variable patterns in the molecular evolution of the hypoxia-inducible factor-1 alpha (HIF-1 $\alpha$ ) gene in teleost fishes and mammals. Gene 420:1-10.

Salazar-Lugo R, Mata C, Oliveros A, Rojas LM, Lemus M and Rojas-Villarroel E (2011) Histopathological changes in gill, liver and kidney of neotropical fish Colossoma macropomum exposed to paraquat at different temperatures. Environ Toxicol Pharmacol 3:490-495.

Sanchez-Arguello P, Aparicio N and Fernández C (2012) Linking embryo toxicity with genotoxic responses in the freshwater snail Physa acuta: Single exposure to benzo(a)pyrene, fluoxetine, bisphenolA, vinclozolin and exposure to binary mixtures with benzo(a)pyrene. Ecotoxicol Environ Saf 80:152160.

Schweiki D, Itan A, Soffer D and Keshet E (1992) Vascular endothelial growth factor may mediate hypoxia-initiated angiogenesis. Nature 359:843-845.

Semenza GL (2012) Hypoxia-inducible factors in physiology and medicine. Cell 148:399-408.

Siddiq A, Aminova LR and Ratan RR (2007) Hypoxia Inducible Factor Prolyl 4-Hydroxylase enzymes: Center stage in the battle against hypoxia, metabolic compromise and oxidative stress Neurochem Res 32:931-946.

Silva J, Freitas TRO, Marinho JR, Speit G and Erdtmann B (2000) An alkaline single-cell gel electrophoresis (comet) assay for environmental biomonitoring with native rodents. Genet Mol Biol 23:241-245.

Singh NP, McCoy MT, Tice RR and Schneider EL (1988) A simple technique for quantitation of low levels of DNA damage in individual cells. Exp Cell Res 175:184-191.

Stehr CM, Johnson LL and Myers MS (1998) Hydropic vacuolation in the liver of three species of fish from the US West Coast: Lesion description and risk assessment associated with contaminant exposure. Dis Aquat Org 32:119-135.

Stentiford GD, Massoud MS, Al-Mudhhi S, Al-Sarawi M, AlEnezi M and Lyons BP (2014) Histopathological survey of potential biomarkers for the assessment of contaminant re- lated biological effects in species of fish and shellfish collected from Kuwait Bay, Arabian Gulf. Mar Environ Res 98:60-67.

Taylor PC and Sivakumar B (2005) Hypoxia and angiogenesis in rheumatoid arthritis. Curr Opin Rheumatol 17:293-298.

Terova G, Rimoldi S, Corà S, Bernardini G, Gornati R and Saroglia M (2008) Acute and chronic hypoxia affects HIF$1 \alpha$ mRNA levels in sea bass (Dicentrarchus labrax). Aquaculture 279:150-159.

Tintos A, Gesto M, Miguez JM and Soengas JL (2008) bNaphthoflavone and benzo(a)pyrene treatment affect liver intermediary metabolism and plasma cortisol levels in rainbow trout Oncorhynchus mykiss. Ecotoxicol Environ Saf 69:180-186.

Tsukatani H, Tanaka Y, Sera N, Shimizu N, Kitamori S and Inoue N (2003) Validity of mutagenic activity as an indicator of river water pollution. Environ Health Prev Med 8:133-138.

Val AL and Honczaryk A (1995) Criando Peixes na Amazônia. INPA, Manaus, $160 \mathrm{p}$.

Van Beneden RJ, Henderson KW, Blair DG, Papas TS and Gardner HS (1990) Oncogenes in hematopoietic and hepatic fish neoplasms. Cancer Res 50(Supplement):5671s-5674s.

Varanasi U, Stein JE and Nishimoto M (1989) Biotransformation and disposition of PAH in fish. In: Varanasi U (ed) Metabolism of Polycyclic Aromatic Hydrocarbon in the Aquatic Environment. CRC Press, Boca Raton, pp 93-150.

Vásquez, K.L. (2009) Ontogenia das Enzimas Digestivas do Tambaqui, Colossoma macropomum (CUVIER, 1818): Subsídios para a Aquicultura. Tese de Doutorado, Manaus, 2009.

Vienneau DS, DeBoni U and Wells PG (1995) Initiation of micronuclei by benzo(a)- pyrene and benzo(e)pyrene in UDP-glucuronosyltransferase-deficient cultured rat skin fibroblasts. Cancer Res 55:1045-1051.

Yu RMK, Ng PKS, Tan T, Chu DLH, SunWu RS and Kong RYC (2008) Enhancement of hypoxia-induced gene expression in fish liver by the aryl hydrocarbon receptor (AhR) ligand, benzo[ $a]$ pyrene $(\mathrm{B} a \mathrm{P})$. Aquat Toxicol 90:235-242.

Zhong H, De Marzo AM, Laughner E, Lim M, Hilton DA, Zagzag D, Buechler P, Isaacs WB, Semenza GL and Simons JW (1999) Overexpression of hypoxia-inducible factor $1 \alpha$ in common human cancers and their metastasis. Cancer Res 59:5830-5835.

Associate Editor: Daisy Maria Fávero Salvadori

License information: This is an open-access article distributed under the terms of the Creative Commons Attribution License (type CC-BY), which permits unrestricted use, distribution and reproduction in any medium, provided the original article is properly cited. 